\title{
ARTICLES
}

\section{HYPERTENSION AND COVID-19}

\section{Mr. Israel Jeba Prabu, D* | Dr. C.P. Sharma**}

*Ph.D. Scholar, Himalayan University, Itanagar, Arunachal Pradesh, India.

**Research Supervisor, Himalayan University, Itanagar, Arunachal Pradesh, India.

DOI: http://doi.org/10.47211/trr.2021.v07i01.010

\section{ABSTRACT}

The aim of this information sheet is to remind you that a higher risk of COVID-19 infections and complications in people with high blood pressure.

Analysis of early data from both China and the U.S. shows that high blood pressure is the most commonly shared pre-existing condition among those hospitalized, affecting between $30 \%$ to $50 \%$ of the patients. Other health conditions included cancer, diabetes, or lung disease. In Italy, a report said that more than $99 \%$ of people who had died from the virus had one of these conditions -- and $76 \%$ of them had high blood pressure.

Other research shows that people with high blood pressure are also slightly more likely to die from coronavinus. Their risk is about twice as high as that of the overall population.

Key Words: COVID-19\& Hypertension.

\section{ABOUT AUTHORS:}

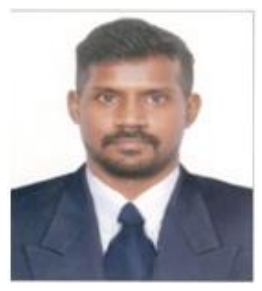

Author Mr. Israel Jeba Prabu, is Ph.D. Research Scholar in Himalayan University, Arunachal Pradesh, India. He is working as Associate Professor, Bee Enn college of Nursing, Jammu, India.

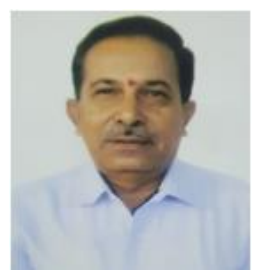

Author Dr. C. P Sharma M.Sc. (N) Medical Surgical Nursing is Research Supervisor in Himalayan University, Arunachal Pradesh, India. 


\section{INTRODUCTION \\ “The pandemic reinforces what we already know. We can't keep people healthy if they don't have a roof over their head and food on the table."}

- Bechara Choucair

Coronavirus disease 2019 (COVID-19) emerged in December 2019 likely as a result of zoonotic transmission from wild animals linked to a large wet market in Wuhan, China.1 The responsible virus, severe acute respiratory syndrome coronavirus 2 (SARS-CoV-2) 1 is a novel coronavirus that belongs to the same family as severe acute respiratory syndrome coronavirus (SARS-CoV) and Middle East respiratory syndrome coronavirus (MERS-CoV). Due to its high transmissibility, COVID-19 spread quickly and escalated into a global pandemic. As of June 18, 2020 the re were over 8 million documented cases and 450,000 deathsworldwide, including more than 2 million cases and 118,000 deathsin the United States (US). 2

Early reports from major COVID-19 epicenters including Wuhan and Lombardy, Italy revealed higher morbidity and mortality rates among patients with a history of hypertension, coronary artery disease, diabetes mellitus, chronic kidney disease, and obesity. Since SARS-CoV-2 infects human cells via the angiotensin-converting enzyme II (ACE2) receptor that acts on the renin-angiotensin-aldosterone system (RAAS), a key regular of blood pressure, questions have been raised about a possible link between hypertension and severe COVID-19 infection. This paper will explore the current state of our understanding of this association and review recently published studies evaluating outcome sof hypertensive COVID-19 patients treated with RAAS inhibitors.

\section{Link between Hypertension and COVID-19}

A weaker immune system is one reason people with high blood pressure and other health problems are at higher risk for coronavirus. Long-term health conditions and aging weaken your immune system so it's less able to fight off the virus. Nearlytwo-thirds of people over 60 have high blood pressure. Another possibility is that the higher risk comes not from high blood pressure itself, but from certain drugs used to treat it -- ACE inhibitors and angiotensin receptor blockers (ARBs). The theory is based on the fact that ACE inhibitors and ARBs raise levels of an enzyme called ACE2 in your body. And to infect cells, the COVID-19 virus must attach itself to ACE2. Some large studies found no ties between the use of these drugs and how severe COVID-19 is. Another research suggests that they may make COVID-19 less severe. There's also no proof that people have less severe illness after stopping them. Stopping these medications may make heart and kidney disease worse. It can also raise your risk of death. The American College of Cardiology and American Heart Association recommend that you keep taking your high blood pressure medicine as prescribed. If you don't, it could raise your risk for a heart attack or stroke, putting you in the hospital just as coronavirus cases are coming in.

\section{How Coronavirus Affects People with High Blood Pressure}

While pneumonia is the most common complication of the virus, it can also damage the cardiovascular system. High blood pressure damages arteries and reduces the flow of blood to your heart. That means your h eart has to work harder to pump enough blood. Overtime, this extra workcan weaken your heart to the point where it can't pump as much oxygen-rich blood to your body. Coronavirus can also damage the heart directly, which can be especiallyrisky if your heart is already weakened by the effects of high blood pressure. The virus may cause inflammation of the heart muscle called myocarditis, which makes it harder for the heart to pump. If you also have plaque build-up in your arteries, the virus may make those plaques more likely to break apart and cause a heart attack. Past studies have shown that people with heart disease who get a respiratoryillness like the flu or earlier types of corona viruses are at higher risk for a heart attack.

\section{What Should You Do?}

Everyone needs to take precautions to prevent coronavirus. People with high blood pressure and other health conditions need to be extra careful.

Some of this advice will help you:

$>$ Make sure you have enough medicine on hand to treat high blood pressure and other health conditions.

$>$ Stock up on over-the-counter medicines to treat a fever and other symptoms if you get sick.

$>$ Stay at home and limit contact with other people as much as you can.

$>$ Avoid crowds and anyone who looks sick. Wear a face mask if you have to be in a public place where you can't stay at least 6 feet away from others.

$>$ Wash your hands often with soap and warm water.

Clean and disinfect all frequently touched surfaceslike countertops and doorknobs.

$>$ Choose heart-healthy foods. Consider the Dietary Approachesto Stop Hypertension (DASH) diet, which focuses on fruits, vegetables, whole grains, poultry, fish and low-fat dairy foods.

$>$ Decrease the salt in your diet. Aim to limit sodium to less than 2,300 milligrams (mg) a day or less. However, a lower sodium intake $-1,500 \mathrm{mg}$ a day or less - is ideal for most adults.

$>$ Lose weight. Losing even a little weight can reduce yourblood pressure. 
- Get active. Regular exercise lowers blood pressure and helps with stress and weight loss.

> Manage stress. When you're stressed, you may cope in unhealthy ways that can raise your blood pressure. Try managing stress in healthy ways, such as deep breathing and meditation.

$>$ Avoid or limit alcohol. Alcohol can raise blood pressure.

$>$ Quit smoking. Tobacco causes blood pressure to rise and plaque to build up quickly in your arteries.

\section{FUTURE DIRECTIONS}

Many questions regarding the effects of hypertension, BP level, BP control, and antihypertensive the rapy have been raised since the beginning of COVID-19 pandemic. A large number of studies have been published over a very short time period, which unfortunately does not guarantee their quality. Many questions remained without adequate answers. This is particularly true for the influence of BP levels and control on outcomes for COVID-19 patients. There is still not enough evidence about the effects of known and newly diagnosed hypertension on the severity and outcomes of COVID-19 for patients. A large number of studies considered the association of different antihypertensive classes of medications with the outcomes in these patients, but almost all of them are retrospective investigations or meta-analyses. It is evident that well-conducted research with a significant number of hypertensive patients is necessary to resolve current controversies in the relationship between hypertension and COVID-19.

\section{CONCLUSION}

The COVID-19 pandemic has taken an enormous toll on human life and efforts to better understand how to prevent and reduce severity of the disease are paramount. While overrepresentation of hypertension has been observed among critically ill COVID-19 patients, our current knowledge is skewed by observational studies that demonstrate an association but do not establish causation. Until more information is available, it is important to treat hypertensive patients to target based on current clinical practice guidelines.

\section{REFERENCE:}

1. Tay MZ, Poh CM, Rénia L, MacAry PA, Ng LFP. The trinity of COVID-19: immunity, inflammation and intervention. Nat Rev Immunol 2020; 20: 363-74.

2. COVID-19 Dashboard by the Center for Systems Science and engineering (CSSE) at Johns Hopkins (Johns Hopkins University \& Medicine website). 2020. Available at: https://coronavirus.jhu.edu/map.html. Accessed 04/30/2020.

3. Arnett DK, Blumenthal RS, Albert MA, et al. 2019 ACC/AHA Guideline on the Primary Prevention of Cardiovascular Disease. J Am Coll Cardiol 2019; 74: e177-232.

4. Fryar CD, Ostchega Y, Hales CM, Zhang G, Kruszon-Moran D. Hypertension prevalence and control among adults: United States, 2015-2016. NCHS Data Brief 2017; 289:1-8.

5. Shah SJ, Stafford RS. Current trends of hypertension treatment in the United States. Am J Hypertens 2017; 30:1008-14.

6. Anon. Coronavirus Update (Live): 4, 852 Cases and 303,584 Deaths from COVID-19 Virus Pandemic Worldometer. Available at: https://www.worldometers.info/coronavirus/. Accessed May 15,2020.

7. Chen N, et al. Epidemiological and clinical characte ristics of 99 cases of 2019 novel coronavirus pneumonia in Wuhan, China: a descriptive study. Lancet. 2020;395(10223):507-13.

8. Vincent JL, Taccone FS. Understanding pathways to death in patients with COVID-19. Lancet Respir Med. 2020; 8:430-432. doi: 10.1016/S2213-2600(20)30165-X

9. Wang D, Hu B, Hu C, et al. Clinical characteristics of 138 hospitalized patients with 2019 novel coronavirusinfected pneumonia in Wuhan, China. JAMA. Epub ahead of print y February 2020. DOl: 10.1001/jama.2020.1585. - DOI - PMC - PubMed

10. Ruan Q, Yang K, Wang W, et al. Clinical predictorsof mortality due to COVID-19 based on an analysis of data of 150 patients from Wuhan, China. Intensive Care Med. Epub ahead of print 3 March 2020. DOI: 10.1007/s00134-020-05991-x. - DOI - PMC - PubMed 